\title{
Regulatory Changes to bank liability structures: implications for deposit insurance design
}

\author{
Kevin Davis* \\ Department of Finance, University of Melbourne \\ and \\ Australian Centre of Financial Studies and Monash University
}

Draft: 26 July 2018

\begin{abstract}
:
"Tiered" depositor (or deposit insurer) preference as exists in Australia and has been recently introduced into the EU and UK calls into question the merits of ex-ante fees for explicit, limited, deposit insurance under such arrangements. This paper illustrates how, under such arrangements, the "fair price" of deposit insurance, and risks to the deposit insurer, are reduced to near zero unless virtually all bank non-equity funding is insured deposits. It is also argued that other regulatory changes affecting bank liability structures and resolution arrangements reinforce that effect, while introduction of "resolution funds" calls into question the rationale for a separate deposit insurance fund. While increased use of collateralised financing complicates resolution arrangements and raises other risks for financial stability, its impact on a "fair price" for deposit insurance under tiered preference is minimal.

KEYWORDS: Deposit Insurance, Bail-in, Implicit Guarantees, Depositor Preference, Option Pricing, Resolution Funds.
\end{abstract}

\section{JEL Categories: G21, G28}

Prepared for Symposium in honour of Professor David Mayes at The University of Auckland on April 9, 2018. David was a good friend and valued colleague and co-author who is sadly missed. He was an important member of the Australia-New Zealand Shadow Financial Regulatory Committee, bringing an all too rare blend of practical knowledge and insights and academic rigour and curiosity to its deliberations.

\footnotetext{
*Contact details: kevin.davis@unimelb.edu.au; +61 383445098.
} 


\section{Introduction}

Explicit, limited, deposit insurance schemes, providing protection from loss up to some limited amount per depositor, have become the norm around the globe, and a component of good principles for financial system safety nets promulgated by international agencies and standard setters. There is also widespread acceptance that the appropriate design of such schemes should involve risk-based fees charged to banks for the protection provided to depositors to reduce moral hazard. There is also widespread support for levying such fees on an ex ante basis to build up a fund available to the deposit insurance agency for use in dealing with bank failures (see Nolte and Khan [1], IADI [2]).

This paper argues that those views have limited relevance under particular types of depositor (and insurer) preference arrangements - including those recently introduced in the EU and UK which are a form of "tiered" preference. The case for a pre-funded, fee based, insurance fund is markedly weakened - provided temporary access to government funding is available for the resolution agency. If, however, implicit guarantees or expectations of "bail out" exist, the increased market discipline benefits associated with tiered preference arrangements are negated and imply a need for alternative arrangements such as a "resolution fund". Similarly, the benefits of tiered preference arrangements (for insurer risks and market discipline) are negated if virtually all bank, non-equity, funding is insured deposits, suggesting a need for regulatory measures to ensure adequate use of non-insured funding.

The origins of conventional views on fee arrangements can be traced back many decades, and arguably reflect experiences arising from the then existing banking structures, priority arrangements, and insurance arrangements. In many countries the experience has been that there have been significant claims on the deposit insurer (Bennett and Unal [3] provide data for the USA), and that even with risk-related fees for deposit insurance, taxpayers have often borne some part of the cost of bank failures due to insufficient funds available to the deposit insurer and/or "bail-outs" of uninsured bank creditors by government. Most recently, the Global Financial Crisis of 2007-2009 led to significant taxpayer costs in many countries, ${ }^{1}$ but also has led to substantial policy changes aimed at preventing future bail-outs and potential costs to deposit insurance schemes. These include: increased adoption of depositor preference arrangements; requirements for non-equity regulatory capital to have "bail-in" conditions; stronger pre-failure resolution powers (see Philippon and Salord [5] for an overview of EU and US developments); and higher capital requirements.

The interdependencies between deposit insurance scheme risks and bank liability structures and resolution arrangements are well known (see FDIC [6]). But the implications have not necessarily found their way through to policy decisions and accepted views about optimal

\footnotetext{
${ }^{1}$ EC [4] states that EU591.9 billion (4.6\% of EU 2-12 GDP) of government capital support was provided between October 2008 and December 2012.
} 
depositor preference arrangements and implications for deposit insurance design. ${ }^{2}$ These interdependencies are relevant for several reasons.

One the one hand, some existing regulatory requirements for liability structures, particularly those involving "tiered depositor/insurer" preference may reduce to (near) zero the risk of deposit insurers not recouping payouts to insured depositors from the resolution of a failed bank. The case for positive deposit insurance fees (and ex ante payment of such) is significantly weakened in such cases. The introduction of "bail-in" requirements for nonequity regulatory capital instruments, if bail-in is credible and supervision sufficiently rigorous, further weakens the case.

On the other hand, the question arises of whether it is optimal to design bank liability regulatory requirements to achieve the outcome of minimal risk to, and potentially eschewing charging of fees by, the deposit insurance scheme. "[J]urisdictions considering introducing depositor preference, or changing their existing depositor preference arrangements, should weigh the advantages and disadvantages in the context of their legal and judicial framework and financial system structure" (IADI [2]). Policies which place insured depositors and the deposit insurer ahead of other claimants in a bank failure, could affect the potential for "runs" by non-insured depositors and creditors. They could also be expected to lead to those other claimants demanding higher promised and/or expected returns for supply of funds to banks. Whether any such market discipline could be sufficient to replace the argued benefits of risk-related deposit insurance fees in reducing moral hazard is an open question. There is also the potential for increased collateralisation requirements by providers of funds which may impact the quality of non-collateralised assets available to meet depositor claims. ${ }^{3}$

Indeed, if market discipline does occur, imposition of deposit insurance fees could in effect amount to a form of "double taxation". This was noted by Birchler [7] who suggested that part of the appeal of depositor preference was that it "protects depositors but preserves market discipline, since depositors are insured by junior lenders to the same bank, rather than by a third party such as an insurance fund or the taxpayer".

In this regard, a recent study by Danisewicz et al [8] is relevant. They use differential adoption of depositor preference by US states between 1983 and 1993, to show that non-insured creditors (depositors, bond holders etc) of banks in states where depositor preference was adopted required higher interest rates associated with their subordination to insured depositors. They also find that overall bank interest costs declined (due to lower rates paid to depositors), and that the composition of bank funding and risk taking changed in such a way as to improve bank soundness. While they suggest that their results provide some support for the recent introduction of depositor preference in the EU, they do not consider implications

\footnotetext{
${ }^{2}$ Birchler [7] notes that "[m]any aspects of deposit priority rules, in particular their joint effects with deposit insurance, may need further investigation".

${ }^{3}$ While some commentators suggest collateralisation reduces the quantity of bank assets available to meet depositor claims, this argument neglects the fact that deposit or other non-collateralised financing should also be correspondingly lower.
} 
for design of deposit insurance schemes nor the implications of different types of depositor preference arrangements.

In practice, deposit insurance agencies play important roles in addition to ensuring compensation of insured depositors. One is to facilitate speedy access to funds by depositors and smooth resolution of failing depository institutions, such as via supported merger with another bank. It is important that there is access to funds to make payments to insured deposits before those amounts can be recouped from the resolution process. But that does not necessarily require the establishment of a fund rather than access to a temporary line of credit from government with insurer payouts recouped from claims on assets of the failed bank (or ex-post levies on other banks if those assets are inadequate).

Another important role is in the supervision of banks, and incentives for optimal performance of that role may be affected by depositor preference and resolution arrangements. Less risk of insurance scheme payouts in the event of a bank failure may reduce incentives to stringent supervision and early intervention, or affect the form of resolution adopted in the event of failure.

The basic argument of this paper is that there is a need to consider more closely the implications for deposit insurance design of recent (and other prospective) changes in bank liability priority structures and resolution arrangements. Those actual and potential changes challenge the apparently widely held view that any deposit insurance scheme should involve risk based, ex ante, fees.

There are, for example, a diverse range of depositor/insurer preference arrangements seen around the globe which have different consequences for deposit insurer exposure to loss. In addition, "bail-in" requirements for AT1 and Tier 2 capital instruments are designed to recapitalise a troubled bank, which if successfully implemented (although largely untested) should reduce or remove deposit insurer exposure to loss. ${ }^{4}$ Similarly the role of capital conservation buffers and enhanced resolution powers should, in principle, work to limit the prospect of a bank failure occurring in which (under some depositor preference and insurer preference arrangements) remaining assets were insufficient to meet insured depositor (and, via subrogation, deposit insurer) claims.

At the same time, a number of countervailing factors are in evidence. Growing use of collateralised financing and netting arrangements reduce the quantum of assets available for dealing with resolution of a failed bank. Whether these increase risks to deposit insurance agencies depends on how their use affects the composition of other financing or the quality of unencumbered assets.

The argument of the paper can be stated briefly as follows. First, under reasonable assumptions, where the deposit insurer has priority over uninsured depositors and other unsecured creditors, the "fair price", reflecting the value of taxpayer / insurance fund

\footnotetext{
4 They also can be interpreted as implying a form of depositor preference over any AT1 and Tier 2 forms of debt financing, even if no general depositor preference applies.
} 
guarantees to insured depositors is extremely close to (if not equal to) zero. (The exception is if the proportion of insured deposits in total bank liabilities is very high.) ${ }^{5}$ Second, uninsured depositors and other creditors could be expected, in these circumstances, to demand appropriate risk-based returns for the "insurance" they provide, via subordination, to "insured" depositors. ${ }^{6}$ Such market discipline would, if present, overcome the moral hazard concerns associated with having no explicit fee for limited deposit insurance. Third, however, if this form of market discipline does not operate due to perceptions of implicit government guarantees ${ }^{7}$, a fee reflecting the value of those implicit guarantees is arguably appropriate (on grounds of both moral hazard prevention and competitive neutrality). Such fees could be used for a "resolution fund" such as exists in some jurisdictions, enabling regulators to arrange takeovers of troubled institutions, or use of other mechanisms, which, by their nature, provide protection to other creditors as well as insured depositors. Fourth, if some types of banks have excessive reliance on insured deposit financing, regulatory requirements to limit or induce reductions in that reliance, such as linking core equity capital requirements to the mix of insured versus uninsured financing, may be worth consideration.

The paper proceeds as follows. First, conventional views on deposit insurance design and pricing are briefly surveyed in section 1 . Section 2 reviews depositor preference arrangements. Section 3 considers the implications of alternative depositor preference arrangements on the "fair value" of limited deposit insurance. Sections 4 and 5 consider the implications of requirements for bail-in AT1 and Tier 2 capital and of collateralised financing on the arguments advanced. Section 6 turns to implications of implicit guarantees and "resolution funds", while Section 7 concludes.

\section{Deposit Insurance Design and Pricing: Contemporary Views}

It is the conventional wisdom that: (a) an explicit, limited, well designed, deposit insurance scheme (DIS) should be a feature of financial system design; and (b) one component of good design is the charging of risk adjusted premiums to banks covered by the scheme. There is also a widespread perception that ex ante premiums (rather than ex post levies) should be charged to member banks, which is reflected in practice. The IADI 2016 survey of member countries found that "[n]early 90 percent of DIS are funded by ex ante contributions from

\footnotetext{
${ }^{5}$ Chan-Lau and Oura [9] find that in their analysis "[t]he cost of preferred deposits, declines to only a few basis points above risk-free rate even without the support from a deposit guarantee scheme ...as long as the share of preferred deposits remains below 60 percent of total liabilities." IADI [2] advocate that a substantial proportion by value of deposits should be uninsured. Cannas et al [10] estimate the share of covered to total deposits for the EU in 2013 to be just under 50 per cent.

${ }^{6}$ Reuters [11] report that Fitch Ratings, for example, noted that the introduction of depositor preference in Europe could raise the effective asset encumbrance ratio, from the perspective of unsecured creditors, from 28 to 72 per cent with significant implications for recovery rates in the case of insolvency.

${ }^{7}$ Schich et al [12] note from a study of European banks that "Implicit guarantees persist however and their value continues to be significant" despite some decline in the last few years associated with developments in bank regulation and resolution arrangements.
} 
their member institutions" with an increasing trend towards use of non flat rate premium structures (IADI [13]). ${ }^{8}$

There is less agreement in the academic or policy literature on the merits of ex ante rather than ex post funding. Demirgurc-Kunt et al [15] spell out six core principles which include limited coverage, a design which prevents taxpayer loss (except in extreme circumstances), and appropriate risk-based pricing, but do not explicitly include charging ex ante premiums in those principles. The IMF [16] argues for risk related premiums, but notes the relative strengths and weaknesses of ex ante versus ex post scheme funding. The FSB [17] suggests that there "may be merits to the broader adoption of ex-ante funding arrangements, and IADI should consider whether a pre-funded DIS needs to be more explicitly advocated in its guidance". That referred to a 2009 IADI document, and in its updated principles document IADI [2] includes in Principle 9 adequate scheme pre-funding arrangements including ex-ante fees. They do not specifically however endorse risk based premiums.

Notably, these views have been developed over time from global experiences under particular institutional arrangements including either an absence of depositor preference or general, rather than "tiered", depositor preference arrangements.

\section{Depositor Preference}

Some form of depositor preference, which gives depositors seniority over most other creditors in a bank insolvency, has existed for decades in a small number of countries (such as Switzerland since 1934, Australia since 1945 and the USA since 1993). It has now come under consideration and been introduced in a number of other jurisdictions (such as the EU and UK) primarily as a measure perceived to increase financial stability. It has also been recommended for consideration in some recent Financial Sector Assessment Programs conducted by the IMF. ${ }^{9}$ The FSB [17] noted that 13 of its 21 members provided some form of depositor preference. At the end of 2013, 62 of 99 deposit insurers reported to IADI that some form of depositor preference prevailed in their jurisdiction, and the subsequent EU and UK changes would have increased that proportion significantly. ${ }^{10}$

Much of the recent focus of depositor preference discussion has been on financial stability considerations and clarifying bank resolution arrangements, particularly for ensuring that retail (or other) depositors do not get caught up in bail-in situations. ${ }^{11}$ But, of course, such

\footnotetext{
${ }^{8}$ Demirgüç-Kunt et al [14] note that 88 per cent of the countries in their survey with explicit deposit insurance schemes use ex ante funding.

${ }^{9}$ See for example IMF $[18,19,20]$.

${ }^{10}$ Data provided by IADI from its 2014 survey. Very few EU countries at that time had depositor preference. The figures are also affected by multiple deposit insurance agencies reporting from some jurisdictions.

${ }^{11}$ One country which has explicitly eschewed this route is New Zealand, whose Open Bank Resolution approach involves bail-in, by way of haircut, applied pro rata to all unsecured bank creditors including depositors.
} 
changes to creditor priority arrangements can be expected to have consequences for required returns of affected creditors, increasing them for less preferred relative to more preferred creditors. ${ }^{12}$ Greater preference status also, ceteris paribus, reduces the likelihood that in an insolvency preferred creditors such as insured depositors, and thus potentially the deposit insurance fund (via subrogation), will suffer losses, and need to be taken into account when considering how to calculate "fairly priced" deposit insurance and risk of loss to a deposit insurer.

Table 1 depicts a simplified depiction of the liability side of a bank balance sheet, highlighting that there are typically a number of different categories of providers of funds including insured depositors, uninsured depositors, other creditors and shareholders. ${ }^{13}$ Preference arrangements among these stakeholders differ across nations. The simplified balance sheet also ignores distinctions between deposits of residents and non-residents and between which there may be different preference arrangements.

\footnotetext{
${ }^{12}$ Many commentators have expressed concerns that depositor preference will increase incentives of less preferred stakeholders to "run".

${ }^{13}$ In practice, there will be other liabilities in insolvency such as unpaid employee entitlements, tax liabilities etc which, depending upon national legislation, may rank ahead of insured deposits or the insurer in liquidation. So also will collateralised claims.
} 
Table 1: Simplified Bank Balance Sheet Liability Structure

\begin{tabular}{|l|}
\hline LIABILITIES (Approximate Seniority Order) * \\
\hline Derivative Liabilities (where collateralisation or netting applies) \\
\hline Covered Bonds (where bonds are secured against cover pool of assets) \\
\hline Repos (where funds borrowed have involved asset sale to lender) \\
\hline Insured Deposits \\
\hline Uninsured Deposits - retail \& wholesale \\
\hline Bank Accepted Bills / CDs \\
\hline Senior Debt \\
\hline Subordinated Debt / Unsecured Creditors \\
\hline Tier 2 Regulatory capital (“bail in" debt / preference shares) \\
\hline AT1 regulatory capital (“bail in" debt / preference shares) \\
\hline Common Equity \\
\hline
\end{tabular}

*This ignores "operational liabilities such as employee entitlements, tax liabilities, and fees payable to a liquidator in the event of liquidation, which may stand ahead of all unsecured debts in a liquidation process.

It is possible to categorise depositor preference arrangements into at least four categories. ${ }^{14}$ Denoting insured deposits by $D_{1}$, uninsured deposits as $D_{\cup}$, other (unsecured) creditors as $C$, and using the symbols ${ }_{>}^{S}$ and ${ }_{=}^{S}$ to represent greater seniority and equal seniority respectively these categories are:

(a) tiered deposit preference $\mathrm{D}_{1}{ }_{>}^{S} \mathrm{D} \cup_{>}^{S} \mathrm{C}$

(b) insured deposit preference only $\mathrm{D}_{1}{ }_{>}^{S} \mathrm{D} \cup{ }_{=}^{S} \mathrm{C}$

(c) general deposit preference $\mathrm{D}_{\mathrm{I}}{ }_{=}^{S} \mathrm{D} \mathrm{U}_{>}^{S} \mathrm{C}$

(d) no depositor preference $\mathrm{D}_{\mathrm{I}} \stackrel{S}{=} \mathrm{D}_{\mathrm{u}^{S}}^{S} \mathrm{C}$.

Table 2 provides (at the risk of over-simplification, given the variety of national arrangements and practices) some examples of national arrangements and how these are reflected in priority of the deposit insurer.

\footnotetext{
14 The FSB [21] identifies four categories: general depositor preference; national depositor preference; eligible depositor preference (preference to categories of deposit eligible for deposit insurance, even if above the maximum cap); insured depositor preference. This ignores "tiered" preference arrangements.
} 


\begin{tabular}{|c|c|c|c|c|}
\hline & \multicolumn{4}{|c|}{ Depositor Preference Regime } \\
\hline & Tiered & Insured Only & General & None \\
\hline Deposit Insurer Priority & $\mathrm{D}_{1}{ }_{>}^{S} \mathrm{D} \cup_{>}^{S} \mathrm{C}$ & $\mathrm{D}_{1}{ }_{>}^{S} \mathrm{D}_{u} \stackrel{S}{=} \mathrm{C}$ & $\mathrm{D}_{1} \stackrel{S}{=} \mathrm{D} \cup_{>}^{S} \mathrm{C}$ & $\mathrm{D}_{\mathrm{I}}{ }_{=}^{S} \mathrm{D} \mathrm{U}_{=}^{S} \mathrm{C}$ \\
\hline $\begin{array}{l}\text { Ahead of Uninsured Depositors and } \\
\text { General Creditors }\end{array}$ & $\begin{array}{l}\text { EU } \\
\text { UK } \\
\text { Indonesia }\end{array}$ & $\begin{array}{l}\text { Hong Kong } \\
\text { Switzerland }\end{array}$ & $\begin{array}{l}\text { Australia } \\
\text { Singapore }^{a}\end{array}$ & \\
\hline $\begin{array}{l}\text { Equal to Uninsured Depositors and } \\
\text { ahead of General Creditors }\end{array}$ & & & $\begin{array}{l}\text { USA } \\
\text { Malaysia } \\
\text { Russia } \\
\text { China } \\
\text { Taiwan b }\end{array}$ & \\
\hline $\begin{array}{l}\text { Equal to Uninsured Depositors and } \\
\text { General Creditors }\end{array}$ & & & India & $\begin{array}{l}\text { Canada } \\
\text { Brazil } \\
\text { Japan } \\
\text { Norway } \\
\text { Sweden } \\
\text { Korea }\end{array}$ \\
\hline
\end{tabular}

At one extreme is tiered deposit preference arrangement where insured deposits have preference above other creditors including uninsured deposits. In general this translates directly into deposit insurer priority. In the UK, the Financial Services (Banking Reform) Act 2013 (UK Government [22]) introduced (from end 2014) preferential status for deposits protected by the Financial Services Compensation Scheme (FSCS) with the scheme inheriting that status (via subrogation) for any claims it pays out. Subsequent legislation meant that unprotected retail and SME deposits rank next and above other unsecured claims from March 2015. 
Arrangements announced by the EU (EC [4] and implemented in the Bank Recovery and Resolution Directive (EC [23]) created a similar situation from the start of 2015 for EU countries. Essentially, retail (and SME) depositors ${ }^{15}$ have preference over other depositors and creditors, while the deposit insurance scheme (which would pay out covered retail deposits) has preference over all other creditors (including uncovered retail depositors). ${ }^{16}$

In Switzerland and Hong Kong, insured deposits have preference, but uninsured deposits do not, (Hardy [24], Turner [25]). The deposit insurer has priority over uninsured depositors and unsecured creditors. ${ }^{17}$

Australia is one of a number of countries, including the USA, with general depositor preference. However, the provisions of its Financial Claims Scheme legislation mean that in a bank insolvency the deposit insurer (APRA) pays out insured deposits and then has priority over all other creditors (including uninsured depositors) in liquidation. In Singapore, general depositor preference applies, but the insurer has priority over deposit claims of other banks on the failed bank.

If the insurer ranked equally with uninsured depositors who ranked ahead of other creditors, the system would correspond to case (c) of general deposit preference. This corresponds to the case of the USA where, since 1993, depositors have had preference over other creditors, but where the FDIC does not have preference over uninsured depositors in liquidation. It is noteworthy that the FDIC's experience of losses involved in resolving troubled banks have been significant and, together with moral hazard concerns, appear to be one factor in shaping academic views on appropriate deposit insurance design. ${ }^{18}$

At the other extreme are many countries where creditors and depositors have equal preference, although there may be specific categories of subordinated debtholders (and increasingly holders of debt which can be "bailed in").

More generally, and complicating preference arrangements have been the growth of various forms of collateralised borrowing by banks, including repurchase agreements and covered bond issuance. For ease of exposition, these complications are ignored in the next section

\footnotetext{
${ }^{15}$ This includes deposits in overseas branches which would have otherwise been eligible.

${ }^{16}$ The unification of member country national deposit insurance schemes into a unified EU scheme is under discussion at the time of writing.

${ }^{17}$ China has local depositor preference and announced in December 2014 the forthcoming introduction of a deposit insurance scheme, but details on preference status of the insurer are not readily available.

${ }^{18}$ The number and size of losses from bank failures impacting on the FDIC fund suggest that even though the FDIC has preference (since 1993) over other (non-depositor) creditors, an important determinant may be the proportion of insured deposits to bank liabilities. At the aggregate level, at the end of 2017, insured deposits at FDIC insured banks were 53 per cent of total deposits and 46 per cent of total liabilities (FDIC [26]. O'Keefe and Ufier [27] however report that the proportion of deposits insured decreases with size, and was 74 per cent for banks with assets between $\$ 1$ to $\$ 10$ billion, and 97 per cent for the small sample of failed banks between 1984 and 2016 with assets under \$1 billion for which data was available. Over the period 1990-2017 (excluding 2007-2010, when the figure was $\$ 4.4$ billion) the average size of failed institutions was $\$ 270$ million).
} 
(but considered in section 5) which examines the consequences of various levels of depositor preference in the typical situation where deposit insurance only applies to a subset of deposits (such as retail deposits below some "capped" level). Also ignored are the consequences of domestic $v$ international depositor preference which while important are less relevant to the principal message of this paper.

\section{The impact of depositor preference on deposit insurance valuation}

Merton [28] introduced the notion of considering deposit insurance using option pricing concepts, and his method of estimating an actuarially "fair price" for provision of deposit insurance has influenced subsequent research and practice. A range of different option pricing models involving variants upon and extensions to his original model, and extensions to modelling the overall loss distribution of the deposit insurer can be found in the literature. See, for example, [29], [30], [31], [32], [33], [34 ], [35 ]. ${ }^{19}$

Merton assumed that the only non-equity liabilities of the bank were insured deposits, such that the net payout by the insurer was equal to deposit liabilities less the recovery value of the failed bank's assets. Others such as Marcus and Shaked [30] allowed for a mix of insured and uninsured deposits (creditors) assuming that the deposit insurer had no priority over uninsured depositors (creditors) of claims on the failed bank assets, (as was the case of the FDIC at that time). ${ }^{20}$

Other researchers (Geske [36] and Black and Cox [37] are early examples) have examined the situation in which some claimants on a failed firm's assets, such as subordinated debt holders, have a priority claim over others, but there have been relatively few applications to bank liability priority structures. An exception is the work of Osterberg and colleagues [38-40] in analysing the introduction of depositor preference laws into the USA. Those papers allowed for the existence of general creditors subordinated to depositors, and used the CAPM to assess the effects of the shift to depositor preference on the cost of debt and value of the FDIC position, but assuming underpriced deposit insurance.

Laeven [41] applies an option pricing approach to illustrate the implication of the case where the bank also has other non-deposit debt claims on issue. If there is no depositor preference, then the value of deposit insurance per dollar of insured deposits is unaffected. He also conducts an experiment using Korean bank data where he assumes that general depositor preference applies such that non-deposit debt is treated as subordinated. He demonstrates

\footnotetext{
${ }^{19}$ Even though national deposit insurers may not use such explicit option pricing models in determining premiums, risk based pricing approaches typically reflect similar considerations and, in principle, aim to (a) achieve appropriate compensation for the insurance scheme (or taxpayers) for the value of insurance provided, and (b) reduce the incidence of moral hazard.

${ }^{20}$ While they did not explicitly consider non-depositor creditors, in the absence of depositor preference their analysis can be interpreted to include other creditors with uninsured depositors.
} 
that this leads to a reduction in the value of deposit insurance per dollar of insured deposits relative to the case where there is no depositor preference. ${ }^{21}$

This brief overview of prior approaches to deposit insurance valuation under alternative depositor preference arrangements suggests that the full effects of different types of depositor preference have not been generally considered. Figure 1 provides an overview of the consequences of alternative arrangements by looking at the differences in the net payout of the deposit insurer, using a simple one-period option pricing framework. ${ }^{22} \mathrm{~B}_{\mathrm{i}}, \mathrm{B}_{\mathrm{u}}$ and $\mathrm{B}_{\mathrm{c}}$ are the end of period claims of insured depositors, uninsured depositors and general creditors respectively. $A$ is the value of the bank's assets at the end of the period. Bankruptcy occurs if $A<B_{i}+B_{u}+B_{c}$ and the insurer pays out $B_{i}$. With no depositor preference, the deposit insurer then has a claim of $\operatorname{Min}\left[B_{i}, \frac{B_{i}}{B_{i}+B_{u}+B_{c}} A\right]$ on the bank assets, such that there is always a net payout when bankruptcy occurs since $A<B_{i}+B_{u}+B_{c}$. (The insurer pays out $B_{i}$ and recoups less than $\left.B_{i}\right)$. With general depositor preference the insurer's claim is $\operatorname{Min}\left[B_{i}, \frac{B_{i}}{B_{i}+B_{u}} A\right]$ and a net payout occurs only if $A<B_{i}+B_{u}$. With tiered depositor preference the insurer's claim is $\operatorname{Min}\left[B_{i}, A\right]$ and a net payout occurs only if $\mathrm{A}<\mathrm{B}_{i}$.

It is immediately apparent that the value of the put option written by the deposit insurer declines as the preference arrangements shift from no preference to general depositor preference to tiered depositor preference. (This is both in aggregate, and per dollar of insured deposits - which are held constant in these comparisons of preference arrangements). As Figure 1 illustrates, the consequences of insured depositor/insurer tiered preference on the "fair value" of insurance depends upon the mix of insured deposits, uninsured deposits and general creditors. How substantial is the effect?

Figure 1: Insurer Net Payouts under Alternative Preference Arrangements

\footnotetext{
${ }^{21}$ In this experiment, Laeven infers that uninsured debt is treated as equivalent to equity which would understate the reduction in the value of deposit insurance since the implied bankruptcy level of assets (and strike price of the put option used in calculating the insurance premium value) is lower than is actually the case.

${ }^{22}$ For ease of exposition it is assumed that the deposit insurer inherits the priority status of insured depositors.
} 


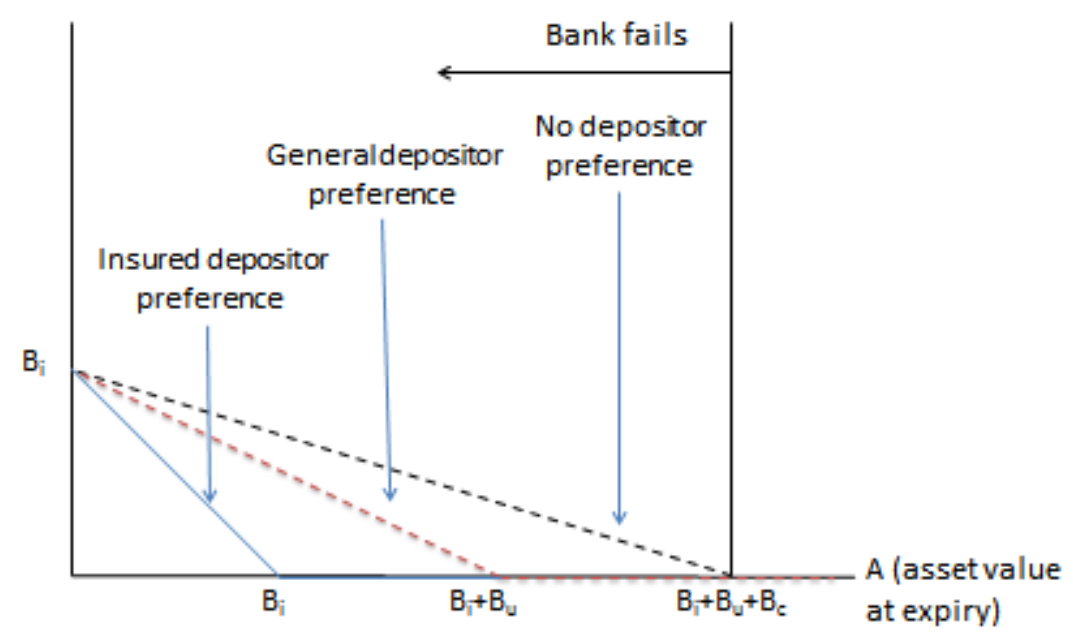

The effects of differences in depositor preference arrangements depend on the mix of funding used by the bank, but are dramatic for reasonable, realistic, cases. To illustrate, we use the simple model of Ronn and Verma [31] and choose conservative parameters which imply a considerable overstatement of the probability of failure under the assumed stochastic behaviour of bank assets. We set insured deposits/assets at either 0.8 or 0.7 , equity/assets at 0.05 with varying combinations of uninsured deposits and unsecured creditors comprising the rest of bank funding. We assume an asset variance of $\sigma^{2}=0.006$, following Merton [28], and use a one year horizon ( $T=1)$.

Table 3 shows the consequences of alternative assumptions regarding the relative size of insured deposits versus other funding and different assumptions regarding depositor preference. Case (a) corresponds to Merton's deposit/assets $=0.95$ case, and the fair value of $\$ 1.21$ per $\$ 100$ of insured deposit equals his estimate for no or general depositor preference. (The total value is proportionately lower reflecting lower insured deposits. Since there are no other creditors, there is no difference between no and general depositor preference in this case). Note the marked reduction in the fair value of insurance to 0.5 cents per $\$ 100$ of insured deposits in the case of tiered depositor preference. Intuitively, this reflects the fact that there needs to be approximately a three standard deviation fall in the value of assets before the insurer is required to make a net payout.

Cases (b) and (c) illustrate how the introduction of other creditors who are subordinated to depositors also has a marked effect on the fair value of insurance under general depositor preference. The reason is that, from the insurer's perspective, under depositor preference, 
an increase in other creditors is similar to an increase in equity. ${ }^{23}$ Case (d) illustrates how a reduction in the proportion of insured deposits also has a significant effect on the fair value, reducing it to 0.4 cents per $\$ 100$ in this example under general depositor preference and to effectively zero under tiered depositor preference.

Table 3: Depositor Preference and Deposit Insurance "Fair Value" Examples ${ }^{a}$

\begin{tabular}{|l|l|l|l|l|}
\hline & \multicolumn{3}{l}{ Cases } \\
\hline Funding Mix & (a) & (b) & (c) & (d) \\
\hline Insured Deposit (Di)\% of assets (BV) & 0.8 & 0.8 & 0.8 & 0.7 \\
\hline Uninsured Deposit (Du)\% of assets (BV) & 0.15 & 0.1 & 0.05 & 0.1 \\
\hline Other Creditors (C)\% of assets (BV) & 0 & 0.05 & 0.1 & 0.15 \\
\hline Equity \% of assets (BV) & 0.05 & 0.05 & 0.05 & 0.05 \\
\hline Depositor Preference Assumptions & Fair Value per \$100 of insured deposits \\
\hline No depositor preference & $\$ 1.21$ & $\$ 1.21$ & $\$ 1.21$ & $\$ 1.21$ \\
\hline General Depositor Preference & \$1.21 & $\$ 0.82$ & $\$ 0.27$ & $\$ 0.004$ \\
\hline Tiered Depositor Preference & $\$ 0.005$ & $\$ 0.005$ & $\$ 0.005$ & $\$ 0.000004$ \\
\hline
\end{tabular}

(a) Calculations are based on an adaptation of the Ronn and Verma [31] model which allows for depositor preference. An annual dividend of 0.2 per cent of assets and $\sigma^{2}=0.006$ is assumed and the time horizon assumed is to be one year.

These calculations are purely illustrative of the general point that tiered preference arrangements can have dramatic effects on the fair value of deposit insurance and insurer risk of loss. More complex models will yield different numbers but the same pattern of results.

For a more intuitive example, consider the case of Australia. Insured deposits of the major banks are around 30 per cent of total (book value) assets, and the insurer has priority over uninsured depositors and other creditors. Uninsured deposits are approximately 30 per cent of assets. With no depositor preference a fair value (using a similar approach to above, and with asset volatility calculated from historical equity volatility) is around $\$ 0.11$ per $\$ 100$ of insured deposits. But under general depositor preference, the fair value falls to a very, very, small fraction of a basis point per $\$ 100$ of insured deposits and is infinitesimal under tiered

\footnotetext{
${ }^{23}$ It is not identical since the point of bankruptcy differs. The tiered depositor preference result is the same for cases $\mathrm{a}, \mathrm{b}$ and $\mathrm{c}$ because the proportion of insured depositors is held constant.
} 
preference. For the insurer to suffer loss, the value of assets would need to fall by over 70 per cent!

Even for the case of building societies and credit unions which have quite different balance sheet structures (with insured deposits around 75 per cent of the value of assets), fair pricing is insignificantly different from zero under tiered depositor preference.

\section{Bail-in requirements and deposit insurance pricing}

Bail-in requirements for AT1 and Tier 2 regulatory capital have been introduced in many jurisdictions and significant issues of securities with such features have been made worldwide. ${ }^{24}$ Additional bail-in debt TLAC requirements for large internationally active banks are also in progress. One consequence of these changes is that there is another layer of bank creditors subordinated to insured (and other) depositors, with obvious, if hard to quantify, implications for the value of explicit limited deposit insurance guarantees.

The complications in assessing the impact of bail-in debt for deposit insurance pricing lie in assessing its impact on probability of bank failure (and consequent activation of explicit deposit insurance schemes) and the likely cost to the scheme in that event. ${ }^{25}$ Triggers for write down or conversion into equity generally involve some element of regulatory discretion, and while bail in debt (even AT1) is in practice likely to be "gone concern" loss absorbing capital, bail in could lead to continuation of the recapitalised entity with no claim on the deposit insurance fund for actual payouts to depositors. There is no substantive experience to date to indicate the political willingness to enforce bail-in terms, but if used to enable continuity of the bank (under new owners and management) this would reduce the likelihood of regulatory agencies requiring funds to facilitate an exit of a failing banks by way of an assisted takeover.

Assuming that bail in will occur when capital is still positive, the effect of introduction of such liabilities is to further reduce the fair value of explicit deposit insurance, through reducing either the bank probability of default or loss given default for insured depositors. Bail-in adds another layer of complexity to the nature of preference arrangements, but from the perspective of explicit deposit insurance it is (if bail-in is credible) essentially equivalent to an increase in the equity capital buffer.

The more substantive effect lies in the potential effect on market discipline and thus moral hazard incentives. Arguably, holders of such debt will take into account the risk associated with such debt and price their subordinated status into required returns. If bail in is credible, the force of arguments for ex ante risk-based pricing of limited explicit deposit insurance under tiered depositor preference are further reduced.

\footnotetext{
${ }^{24}$ Alternatively, statutory bail-in powers over bank debt funding may be available to the resolution agency without any contractual provisions being included.

${ }^{25}$ A number of other concerns for deposit insurers if bail-in does occur are addressed in IADI [42] including use of agency funds in an inefficient resolution process and dealing with and disposing of any resulting equity stake.
} 


\section{Secured creditors, encumbered assets and deposit insurance pricing}

Banks have increasingly used various forms of secured financing and risk management techniques which lead to encumbrance of assets. Examples include covered bond financing and repo financing, while netting agreements for derivatives similarly provide certain counterparties with a priority claim on some of the bank's assets in the event of a bank failure.

The consequences of such asset encumbrance for deposit insurer payouts are demonstrated in Figure 2 which include secured creditors as claimants (of amount $\mathrm{B}_{\mathrm{sc}}$ ) on the bank. Failure now occurs, as before, when the value of assets falls below the total of claims on the bank (now $\mathrm{B}_{\mathrm{i}}+\mathrm{B}_{\mathrm{u}}+\mathrm{B}_{\mathrm{c}}+\mathrm{B}_{\mathrm{sc}}$ ). However, the priority of the secured creditors means that the assets available to the deposit insurer to recoup payments made to insured depositors is the smaller amount $\left(B_{i}+B_{u}+B_{c}\right)$. Thus, in assessing the "fair value" of the deposit insurance provided, it is necessary to subtract from the current value of assets an amount equivalent to the value owed to secured creditors.

Figure 2: Implications of Secured Creditors for Insurer Net Payout

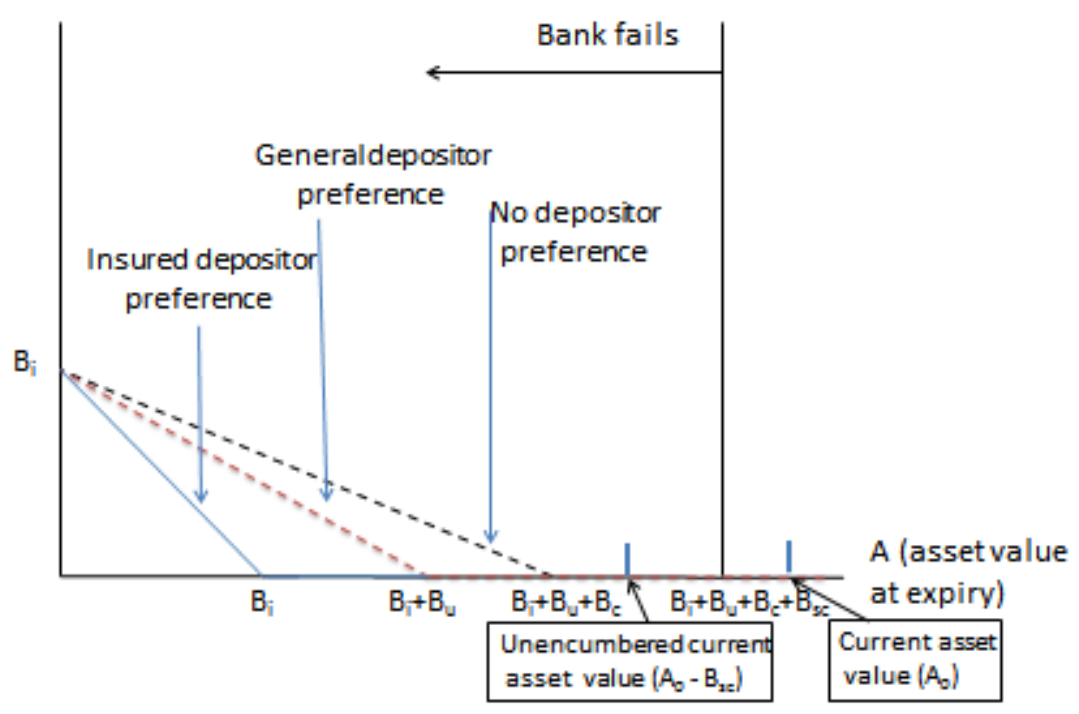

If it is assumed that the value of encumbered assets varies in line with secured creditor financing and does not affect the riskiness or value of unencumbered assets, then secured financing has no impact on the fair value of deposit insurance under tiered depositor preference. (The insurer has first claim on the unencumbered assets). However, under general or no depositor preference, the fair value of deposit insurance and risk of loss to the insurer will increase if unsecured creditors switch to secured creditor status. (The buffer provided by unsecured creditors declines). 
Secured funding and encumbered assets can make a difference to the fair pricing of deposit insurance, but under tiered depositor preference, a non-zero value requires a balance sheet structure with high insured deposits, high secured funding and few uninsured deposits or other unsecured creditors.

\section{Implicit Guarantees, Deposit Insurance and Bank Levies}

The preceding sections have argued that under tiered depositor preference arrangements, and with moderate use of insured deposit funding by banks, the "fair value" of explicit insurance approaches zero. The reason is that the likelihood of the insurer facing a net payout after recoveries from remaining bank assets approaches zero due to preference arrangements. It is, effectively, the less preferred stakeholders who are providing the insurance to insured depositors. It would be expected that this would be reflected in their required rates of return on funds provided to the bank. If this were the case, charging a fee for explicit deposit insurance would amount to imposing an unwarranted duplicate cost.

To the extent that there are perceptions of government implicit guarantees for bank creditors through expectations of bail-outs of distressed banks, required returns of non-preferred stakeholders may not incorporate an appropriate risk premium. In those circumstances, the government incurs a cost - but it is unrelated to the "fair value" of explicit deposit insurance. Rather, it reflects the reduction in the cost of funds to the bank arising from, and providing a valuation of the implicit cost to the government, from the implicit guarantees. ${ }^{26}$

It would be inappropriate to charge explicit deposit insurance fees related to the amount of insured deposits as a mechanism for obtaining compensation for the value of implicit guarantees. There is no necessary correspondence between them. Indeed, the value of implicit guarantees is unrelated to the proportion of total liabilities which are covered by explicit insurance, since, under realistic assumptions with tiered depositor preference, there is no net cost to the insurer from the protection of insured deposits. Rather the cost of implicit guarantees is the cost of bailing out other uninsured creditors as part of the resolution arrangements for the bank. ${ }^{27}$

Hupkes [43] notes that a number of jurisdictions have established resolution funds including the Orderly Liquidation Fund established in the US under the Dodd-Frank Act, the Swedish Stability Fund, and notes an EU recommendation for each nation to establish a resolution fund. Subsequently the EU has established a Single Resolution Fund (EC [44]), to be funded by (risk related) levies on banks and credit institutions based on total liabilities less own funds and

\footnotetext{
${ }^{26}$ Merton [28] addressed a similar issue in the context of assessing the value to a bank from the introduction of explicit deposit insurance covering all non-equity (deposit) liabilities. He argued that the value of insurance to the bank is determined by the reduction in the interest rate risk premium it must pay to raise funds. Any underpricing of insurance relative to its "fair value" conditional on the existence of the insurance scheme is an additional benefit to the bank.

${ }^{27}$ It might be argued that recent global regulatory developments, such as increased capital requirements have reduced the value of implicit guarantees. And while they arguably have, it would appear that implicit guarantees remain of value. Schich et al [12] estimate that significant funding cost advantages of around 132 basis points existed in Europe in 2014 as measured by the effect of credit rating uplifts for banks associated with perceived sovereign support.
} 
covered deposits - where the latter are generally subject to levies under national deposit guarantee schemes. The aggregate consequence is levies on the total liabilities less own funds.

In these circumstances, the relevance of having a separate pre-funded deposit insurance fund warrants questioning.

\section{Conclusion}

Tiered depositor (and insurer) preference implies that the case for ex ante risk-related deposit insurance fees is significantly weakened. Risk of loss to the insurer, from non-recoupment of amounts paid to insured depositors, is significantly reduced, to (or near to) zero as long as bank non-equity funding comprises some significant amount of uninsured deposits and unsecured debt. Of course, resolution of failed or failing banks involves the resolution agency incurring other administrative costs, and funding of those is required. However, it is far from clear that this should be derived from fees based on insured deposits rather than on the aggregate balance sheet size and risk of failure as might apply for a "resolution fund". Moreover, under tiered preference arrangements, the conditions under which alternatives to liquidation (such as an assisted transfer of business) might be less costly to the resolution agency would need to be based only on comparison of resolution administration costs and subsidisation of purchases of uninsured deposits and debt. This is because the agency would not incur losses from payout of insured depositors.

In some jurisdictions there may be some types of banks or depository institutions for which use of non-insured funding is miniscule (such as smaller banks in the USA or mutual depository institutions). This could expose the deposit insurer to losses even under a tiered preference structure. One possibility is to establish a separate fee based deposit insurance scheme for such institutions. However, an alternative approach could be to impose regulatory requirements giving such institutions a strong incentive to incorporate some other forms of funding. For example, requiring higher common equity (relative to total assets) as the proportion of insured deposit financing increases would be one possibility.

Whether adoption of tiered depositor (and insurer) preference is an optimal strategy for those jurisdictions currently with other preference arrangements is an open question. However, where it is adopted, substantial changes to design and pricing of limited, explicit, deposit insurance arrangements need to be considered.

\section{REFERENCES}

1. Nolte, J.P. and I.Z. Khan, Deposit Insurance Systems: Addressing emerging challenges in Funding, Investment, Risk-based Contributions \& Stress Testing. 2017, Washington: World Bank.

2. IADI IADI Core Principles for Effective Deposit Insurance Systems. 2014. http://www.iadi.org/en/assets/File/Core\%20Principles/cprevised2014nov.pdf

3. Bennett, R.L. and H. Unal, Understanding the components of bank failure resolution costs. Financial Markets, Institutions \& Instruments, 2015. 24(5): p. 349-389.

4. EC, State aid: Commission's new on-line state aid benchmarking tool shows less aid to banks, in press release IP-13-1301, E. Commission, Editor. 2013, European Commission: Brussels. 
5. Philippon, T. and A. Salord, Bail-ins and bank resolution in Europe. Geneva Reports on the World Economy Special Report, 2017. 4.

6. $\quad$ FDIC Depositor Priority and rights of set-off (netting). 2000. https://www.fdic.gov/deposit/deposits/international/guidance/guidance/depositorypriority. pdf

7. Birchler, U.W., Bankruptcy priority for bank deposits: A contract theoretic explanation. The Review of Financial Studies, 2000. 13(3): p. 813-840.

8. Danisewicz, P., et al., Debt Priority Structure, Market Discipline, and Bank Conduct. The Review of Financial Studies, 2017: p. hhx111-hhx111. https://doi.org/10.1093/rfs/hhx111

9. Chan-Lau, J.A. and H. Oura, Bail-In Power, Depositor Preference, and Asset Encumbrance: The End of Cheap Senior Unsecured Debt? A Structural Pricing Perspective. 2016: Available at SSRN: https://ssrn.com/abstract=2785992 or http://dx.doi.org/10.2139/ssrn.2785992

10. Cannas, G., et al., Updated estimates of EU eligible and covered deposits, in European Commission Joint Research Centre Technical Report. 2014, Institute for the Protection and Security of the Citizen. p. 1-32.

11. Reuters, Fitch: Bank Depositor Preference Still Key Subordination Risk. 2013. https://www.reuters.com/article/fitch-bank-depositor-preference-still-ke/fitch-bankdepositor-preference-still-key-subordination-risk-idUSFit65964420130529

12. Schich, S., M. Bijlsma, and R. Mocking, Improving the monitoring of the value of implicit guarantees for bank debt. OECD Journal: Financial Market Trends, 2014. 2014(1): p. 7-37.

13. IADI, IADI publishes results of its survey on deposit insurance and financial safety net frameworks. 2017. https://www.iadi.org/en/assets/File/Press\%20Releases/IADI_Annual_Survey_2016_Press_R elease.pdf

14. Demirgüç-Kunt, A., E. Kane, and L. Laeven, Deposit insurance around the world: $A$ comprehensive analysis and database. Journal of financial stability, 2015. 20: p. 155-183.

15. Demirgüç-Kunt, A., E.J. Kane, and L. Laeven, Deposit insurance design and implementation: Policy lessons from research and practice. 2006, The World Bank.

16. IMF, Financial Sector Assessment Program: European Union. Deposit Insurance, Technical Note, IMF Country Report No. 13/66. 2013.

17. FSB, Thematic review on Deposit Insurance Systems. 2012, Financial Stability Board: Basel.

18. IMF, Brazil: Financial System Stability Assessment, IMF Country Report No 12/206. 2012, IMF.

19. IMF, Canada Financial Sector Stability Assessment, IMF Country Report No 14/29. 2014.

20. IMF, Japan : Financial System Stability Assessment, IMF Staff Country Reports 17/244. 2017.

21. FSB, Effective Resolution of Systemically Important Financial Institutions - Recommendations and Timelines 2011, Financial Stability Board: Basel.

22. UK Government, Financial Services (Banking Reform) Act 2013, UK Government, Editor. 2013: London.

23. EC, Bank recovery and resolution - Directive 2014/59/EU, E. Commission, Editor. 2014.

24. Hardy, D., Bank resolution costs, depositor preference and asset encumbrance. Journal of Financial Regulation and Compliance, 2014. 22(2): p. 96-114.

25. Turner, G., Depositor protection in Australia. Bulletin of Reserve Bank of Australia December Quarter, 2011: p. 142.

26. FDIC, Assets and Liabilities of FDIC-Insured Commercial Banks and Savings Institutions. 2018, FDIC. https://www.fdic.gov/bank/analytical/qbp/timeseries/balance-sheet.xls

27. O'Keefe, J.P. and A.B. Ufier, Determining the Target Deposit Insurance Fund: Practical Approaches for Data-Poor Deposit insurers, in Deposit Insurance Systems: Addressing emerging challenges in Funding, Investment, Risk-based Contributions \& Stress Testing, J.P. Nolte and I.Z. Khan, Editors. 2017, World Bank: Washington. 
28. Merton, R.C., An analytic derivation of the cost of deposit insurance and loan guarantees an application of modern option pricing theory. Journal of Banking \& Finance, 1977. 1(1): p. 311.

29. Merton, R.C., On the Cost of Deposit Insurance When There Are Surveillance Costs. Journal of Business, 1978. 51(3): p. 439-52.

30. Marcus, A.J. and I. Shaked, The Valuation of FDIC Deposit Insurance Using Option-pricing Estimates. Journal of Money, Credit, and Banking, 1984. 16(4): p. 446-60.

31. Ronn, E.I. and A.K. Verma, Pricing Risk-Adjusted Deposit Insurance: An Option-Based Model. Journal of Finance, 1986. 41(4): p. 871-95.

32. Pennacchi, G.G., A Reexamination of the Over- (or Under-) Pricing of Deposit Insurance. Journal of Money, Credit, and Banking, 1987. 19(3): p. 340-60.

33. Gropp, R. and J. Vesala, Deposit Insurance, Moral Hazard and Market Monitoring. Review of Finance, 2004. 8(4): p. 571-602.

34. De Lisa, R., et al., Modelling deposit insurance scheme losses in a Basel 2 framework. Journal of Financial Services Research, 2011. 40(3): p. 123-141.

35. Maccaferri, S., J. Cariboni, and W. Schoutens, Lévy processes and the financial crisis: can we design a more effective deposit protection? International Journal of Financial Research, 2012. 4(1): p. 5 .

36. Geske, R., The valuation of corporate liabilities as compound options. Journal of Financial and quantitative Analysis, 1977. 12(4): p. 541-552.

37. Black, F. and J.C. Cox, Valuing corporate securities: Some effects of bond indenture provisions. The Journal of Finance, 1976. 31(2): p. 351-367.

38. Osterberg, W.P., The Impact of Depositor Preference Laws. Federal Reserve Bank of Cleveland Economic Review, 1996. 32(3): p. 2-11.

39. Osterberg, W.P. and J.B. Thomson, The Effect of Subordinated Debt and Surety Bonds on the Cost of Capital for Banks and the Value of Federal Deposit Insurance. Journal of Banking and Finance, 1991. 15(4-5): p. 939-53.

40. Osterberg, W.P. and J.B. Thomson, Depositor-Preference Laws and the Cost of Debt Capital. Federal Reserve Bank of Cleveland Economic Review, 1999. 35(3): p. 10-20.

41. Laeven, L., Pricing of deposit insurance. Vol. 2871. 2002: World Bank Publications.

42. IADI, Deposit Insurance and Bail-in: Issues and Challenges. undated. http://www.iadi.org/en/assets/File/Public_Consultation/Bailin_Research_Paper_Final_Draft_for_IADI_Public_Consultation.pdf

43. Hüpkes, E.H. The Role of Deposit Protection and Resolution Policy in Promoting Financial Stability. 2011. IADI Research Conference, BIS.

44. EC, Single resolution mechanism - Regulation (EU) No 806/2014, European Commission, Editor. 2014. 


\section{University Library}

\section{- M M N E R VA A gateway to Melbourne's research publications}

Minerva Access is the Institutional Repository of The University of Melbourne

Author/s:

Davis, $\mathrm{K}$

Title:

Regulatory changes to bank liability structures: implications for deposit insurance design

Date:

2020-03-01

Citation:

Davis, K. (2020). Regulatory changes to bank liability structures: implications for deposit insurance design. Journal of Banking Regulation, 21 (1), pp.95-106. https://doi.org/10.1057/ s41261-019-00094-0.

Persistent Link:

http://hdl.handle.net/11343/258563 